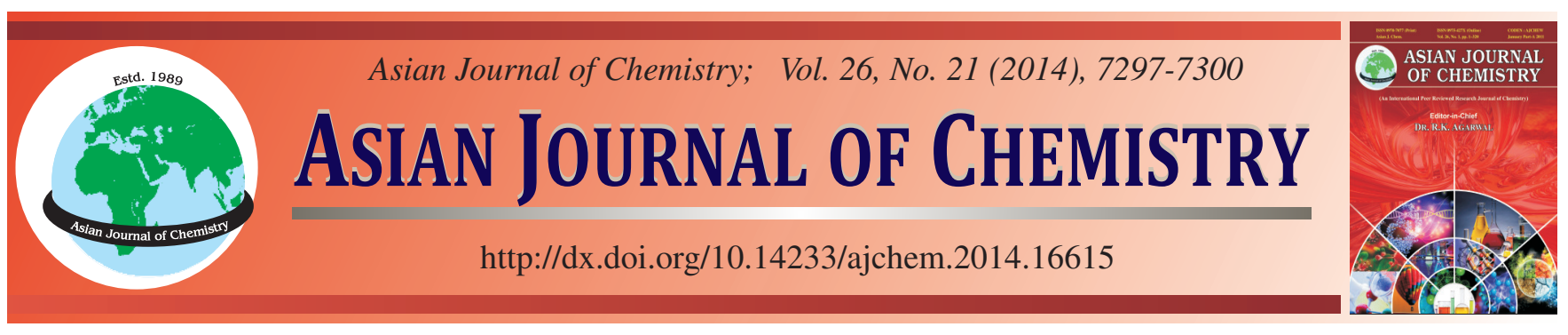

\title{
Synthesis, Crystal Structure and Luminescene of Zinc(II) Complex with 2,6-Pyridinedicarboxylic Acid Radical and 1,10-Phenanthroline
}

\author{
Shu-Yang Chen*, Yun-Rui Huang, Ying-Chen Guo and Yu-Quan Feng
}

College of Chemistry and Pharmacy Engineering, Nanyang Normal University, Nanyang 473061, P.R. China

*Corresponding author: E-mail: shuyang@nynu.edu.cn

Received: 31 October 2013;

Accepted: 18 March 2014;

Published online: 30 September 2014;

AJC-16123

\begin{abstract}
A new zinc(II) complex, $\left[\mathrm{Zn}(\text { pydc })_{2}\right] \cdot\left[\mathrm{Zn}(\text { phen })_{2}\left(\mathrm{H}_{2} \mathrm{O}\right)_{2}\right] \cdot 7.5 \mathrm{H}_{2} \mathrm{O}$, has been synthesized by the reaction of zinc sulfate, 2,6pyridinedicarboxylic acid $\left(\mathrm{pydcH}_{2}\right)$ and 1,10-phenanthroline (phen) and characterized by elemental analysis, IR, UV-visible, TG and X-ray single-crystal diffraction. It crystallizes in triclinic, space group $\mathrm{P} \overline{1}$, with $\mathrm{a}=1.0091(3), \mathrm{b}=1.4799(4), \mathrm{c}=1.4984(4) \mathrm{nm}, \alpha=$ 73.783 (4), $\beta=78.374$ (4), $\gamma=74.886(4)^{\circ}, \mathrm{V}=2.0543$ (9) $\mathrm{nm}^{3}, \mathrm{C}_{28} \mathrm{H}_{41} \mathrm{~N}_{6} \mathrm{O}_{17.5} \mathrm{Zn}_{2}, \mathrm{Mr}=992.36, \mathrm{Z}=2, \mathrm{Dc}=1.574 \mathrm{Mg} / \mathrm{m}^{3}, \gamma(\mathrm{MoK} \alpha)=$ $0.071073 \mathrm{~nm}, \mu=1.252 \mathrm{~mm}^{-1}, \mathrm{~F}(000)=984, \mathrm{~S}=1.040$, the final $\mathrm{R}=0.0412$ and $w \mathrm{R}=0.1335$ for 6128 observed reflections (I $>2 \sigma(\mathrm{I})$ ). The structure unit of the complex consists of two zinc ions with different coordination modes. Each 6-coordinated geometry of the $\mathrm{Zn}$ atom is a distorted octahedral coordination geometry. The complex shows a strong fluorescence emission at around $367 \mathrm{~nm}$ in methanol solution (CCDC: 848466).
\end{abstract}

Keywords: Zinc complex, Crystal structure, Luminescent property.

ᄂ - - - - - - - - - - - - - - - - - - - - - - - - -

\section{INTRODUCTION}

The construction of metal organic complexes is one of the most active research areas of materials due to their interesting properties and various potential applications, such as electrical conductivity, magnetism, host-guest chemistry, ion exchange, catalysis and nonlinear optics ${ }^{1-3}$. Pyridinedicarboxylic acid is an active ligand not only for its multivariate coordination modes with transition metals and rare metals, but also for its biological activities in organism, so its complexes are widely studied and used in the fields of biochemistry and analytical chemistry ${ }^{4-7}$. Zinc is an essential trace element for organism and plays important roles in many vital movements. Some mono- and dinuclear zinc complexes with pyridinedicarboxylic acid ligand have already been observed ${ }^{8,9}$. Though structures of zinc complexes with pydcH $_{2}$ have been studied ${ }^{8}$, there are some crystallographic differences between previous studies and the present one. The changes reflected not only in terms of the number of the crystal water molecules but also in terms of the synthetic methods. A new zinc complex, $\left.\left[\mathrm{Zn}(\text { pydc })_{2}\right] \cdot[\mathrm{Zn} \text { (phen })_{2}\left(\mathrm{H}_{2} \mathrm{O}\right)_{2}\right] \cdot 7.5 \mathrm{H}_{2} \mathrm{O}$, was obtained by using solvent evaporation method. Here we report the synthesis, crystal structure, thermal stability and fluorescence property of the complex.

\section{EXPERIMENTAL}

Zinc sulfate, 1,10-phenanthroline and $\mathrm{NaOH}$ were of analytically pure grade and the purity of 2,6-pyridinedicarboxylic acid was $99 \%$. Elemental analyses (C, H and N) were performed on Vario E1 elementar. Infrared spectra were recorded on a Nicolet 5700 FT-IR spectrophotometer $\left(4000-400 \mathrm{~cm}^{-1}\right)$ using $\mathrm{KBr}$ pellets. UV-visible spectra were recorded on a Lambda 650s UV-visible spectrophotometer. Thermogravimetric analysis was carried out on a Netzsch STA 449C thermal analyzer in flowing $\mathrm{N}_{2}$ atmosphere at a heating rate of $10^{\circ} \mathrm{C} / \mathrm{min}$ from room temperature to $700{ }^{\circ} \mathrm{C}$. The fluorescence property of the complex was tested using a CARY Eclipse fluorescence spectroscopy.

Synthesis of Zn(II) complex: 2,6-Pyridinedicarboxylic acid (1 mmol, $0.17 \mathrm{~g}), 1,10$-phenanthroline (1 mmol, $0.20 \mathrm{~g}$ ) and $\mathrm{NaOH}$ ( $2 \mathrm{mmol}, 0.08 \mathrm{~g}$ ) were dissolved in $20 \mathrm{~mL}$ mixed solvent of $\mathrm{C}_{2} \mathrm{H}_{5} \mathrm{OH} / \mathrm{H}_{2} \mathrm{O}$ by stirring and $\mathrm{ZnSO}_{4} \cdot 7 \mathrm{H}_{2} \mathrm{O}(1 \mathrm{mmol}$, $0.29 \mathrm{~g}$ ) in $10 \mathrm{~mL} \mathrm{H}_{2} \mathrm{O}$ was added slowly and further stirred for $3 \mathrm{~h}$ at room temperature. The resulting solution was filtered and the filtrate was kept at room temperature for several days. Colorless block crystals (Yield: $44 \%$ ) suitable for X-ray diffraction were obtained. Anal. calcd. (\%) for $\mathrm{C}_{38} \mathrm{H}_{41} \mathrm{~N}_{6} \mathrm{O}_{17.50} \mathrm{Zn}_{2}$ : Calcd. (\%): C, 46.00; H, 4.13; N, 8.47. Found (\%): C, 45.87; 
$\mathrm{H}, 4 ; \mathrm{N}, 8.21$. IR (KBr, $\left.v_{\max }, \mathrm{cm}^{-1}\right) 3429$ (s); 1626 (s); 1584 (m); 1520 (w), 1430 (m), 1364 (s), 728 (m), 678 (w).

$\mathrm{X}$-ray crystallographic determination: $\mathrm{X}$-ray diffraction data were collected at 296 (2) K on a Bruker SMART APEXII CCD diffractometer equipped with a graphite-monochromated $\mathrm{MoK}_{\alpha}$ radiation $(\lambda=0.71073 \mathrm{~nm}$ ) by using a $\phi-\omega$ scan mode. In the range of $1.79 \leq \theta \leq 25^{\circ}$, a total of 10523 reflections together with 7182 unique ones $\left(\mathrm{R}_{\mathrm{int}}=0.0136\right)$ were collected and 6128 observed reflections with $\mathrm{I}>2 \sigma(\mathrm{I})$ were used in the succeeding refinements. The structure was solved by direct methods using SHELXS-97 program ${ }^{10}$ and refined with SHELXL-9 $7^{11}$ by full-matrix least-squares techniques on $\mathrm{F}^{2}$. The hydrogen atoms of water molecules in complex were not added. All non-hydrogen atoms were refined anisotropically and hydrogen atoms isotropically by full-matrix least-squares refinement. The final cycle of refinement converged to $\mathrm{R}=$ 0.0412 and $w R=0.1335\left(w=1 /\left[\sigma^{2}\left(F_{o}{ }^{2}\right)+(0.0987 \mathrm{P})^{2}+0.9035\right.\right.$ $\mathrm{P}]$, where $\left.\mathrm{P}=\left(\mathrm{F}_{\mathrm{o}}{ }^{2}+2 \mathrm{Fc}^{2}\right) / 3\right),(\Delta / \sigma)_{\max }=0.000,(\Delta \rho)_{\max }=1.430$ and $(\Delta \rho)_{\min }=-0.789 \mathrm{e} / \AA^{3}$. The selected bond lengths and bond angles are listed in Table- 1 .

\section{RESULTS AND DISCUSSION}

Crystal structure: The crystal structure and packing diagram of the complex are shown in Figs. 1-3, respectively. The two zinc atoms in the complex $\left[\mathrm{Zn}(\text { pydc })_{2}\right] \cdot\left[\mathrm{Zn}(\text { phen })_{2}\left(\mathrm{H}_{2} \mathrm{O}\right)_{2}\right]$. $7.5 \mathrm{H}_{2} \mathrm{O}$ shows two coordination modes (Fig. 1). The $\mathrm{Zn}(1)$ is coordinated with four nitrogen atoms from two 1,10-phenanthroline molecules and two oxygen atoms from two water molecules. The $\mathrm{Zn}(2)$ is coordinated with two nitrogen atoms and four oxygen atoms from two pydc $\mathrm{H}_{2}$ molecules. Each 6coordinated geometry of the $\mathrm{Zn}$ atom is a distorted octahedral coordination geometry. Phen and $\mathrm{pydcH}_{2}$ are bidentate and tridentate ligands, respectively, an anionic $\left[\mathrm{Zn}(\text { pydc })_{2}\right]^{2-}$ and cationic $\left[\mathrm{Zn}(\text { phen })_{2}\left(\mathrm{H}_{2} \mathrm{O}\right)_{2}\right]^{2+}$ are formed simultaneously.

In the $\mathrm{Zn}(1) \mathrm{O}_{2} \mathrm{~N}_{4}$ octahedron, $\mathrm{O}(2 \mathrm{~W}), \mathrm{N}(1), \mathrm{N}(3)$ and $\mathrm{N}(4)$ locate at the equatorial plane and $\mathrm{N}(2)$ and $\mathrm{O}(1 \mathrm{~W})$ occupy the axial positions. Bond angles of $\mathrm{O}(2 \mathrm{~W})-\mathrm{Zn}(1)-\mathrm{N}(1), \mathrm{N}(1)-$ $\mathrm{Zn}(1)-\mathrm{N}(4), \mathrm{N}(4)-\mathrm{Zn}(1)-\mathrm{N}(3)$ and $\mathrm{N}(3)-\mathrm{Zn}(1)-\mathrm{O}(2 \mathrm{~W})$ are $89.18(10), 96.06(10), 77.94(10)$ and $97.13(9)^{\circ}$, respectively. The sum of these angles is $360.31^{\circ}$ (close to $360^{\circ}$ ), suggesting a planar nature of $\mathrm{O}(2 \mathrm{~W}), \mathrm{N}(1), \mathrm{N}(3), \mathrm{N}(4)$ and $\mathrm{Zn}(1)$. Bond
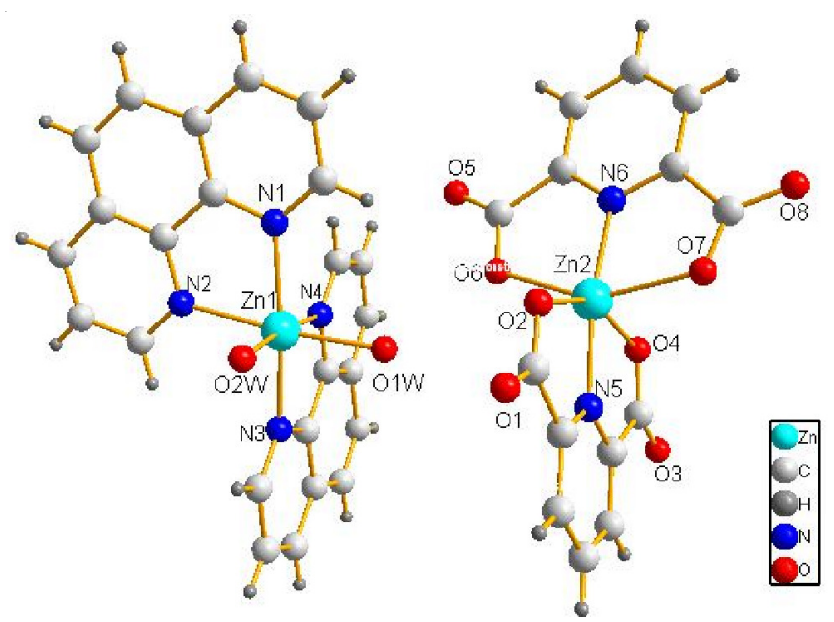

Fig. 1. Molecular structure of the $\mathrm{Zn}$ (II) complex; $\left(\mathrm{H}_{2} \mathrm{O}\right.$ molecules have been omitted for clarity)

angle of $\mathrm{O}(1 \mathrm{~W})-\mathrm{Zn}(1)-\mathrm{N}(2)$ is $174.93^{\circ}$. The dihedral angle between the two phen molecules is $87^{\circ}$.

In the $\mathrm{Zn}(2) \mathrm{N}_{2} \mathrm{O}_{4}$ octahedron, the two planes of $\mathrm{pydcH}_{2}$ molecules is almost vertical, the dihedral angle between them is $89.8^{\circ}$. The angles of $\mathrm{O}(2)-\mathrm{Zn}(2)-\mathrm{O}(4)$ and $\mathrm{O}(6)-\mathrm{Zn}(2)-\mathrm{O}(7)$ are 152.81(9) and $151.99(9)^{\circ}$, respectively, indicating a distorted octahedron.

The complex molecules are arranged in zigzag chain along c axis (Fig. 2). Though the hydrogen atoms of water molecules were not added, but hydrogen bonds could be deduced from the distances of oxygen atoms $(\mathrm{O}(1 \mathrm{~W})$ and $\mathrm{O}(6), 0.270 \mathrm{~nm}$; $\mathrm{O}(2 \mathrm{~W})$ and $\mathrm{O}(4), 0.277 \mathrm{~nm})$. One chain is packed trans to the other forming a column, in which the phen molecules of one chain and $\mathrm{pydcH}_{2}$ molecules of the other are arranged alternately. The columns are stacked and the channels are filled with water molecules (Fig. 3).

IR and UV-visible spectra: In the IR spectrum, a strong and wide adsorption bond around $3429 \mathrm{~cm}^{-1}$ is the characteristic vibration of water. Bands at 1626 and $1364 \mathrm{~cm}^{-1}$ could be attributed to the stretching vibration $\left(\mathrm{v}_{\mathrm{as}(\mathrm{COO}-)}\right.$ and $\left.\mathrm{v}_{\mathrm{s}(\mathrm{COO}-)}\right)$ of coordinated carboxyl. Compared with those of free ligand of 2,6-pyridinedicarboxylic acid $\left(\mathrm{v}_{\mathrm{as}}=1698, \mathrm{v}_{\mathrm{s}}=1458 \mathrm{~cm}^{-1}\right)$, a clearly red shift appears. $\Delta v\left(\Delta v=v_{\text {as(COO- })}-v_{\mathrm{s}(\mathrm{COO}-)}\right)$ is 262

\begin{tabular}{lccccc}
\multicolumn{7}{c}{ TABLE-1 } \\
\multicolumn{7}{c}{ SELECTED BOND LENGTHS (nm) AND BOND ANGLES ( ${ }^{\circ}$} \\
\hline \multicolumn{1}{c}{ Bond } & Dist. & \multicolumn{1}{c}{ Bond } & Dist. & Bond & Dist. \\
\hline $\mathrm{Zn}(1)-\mathrm{N}(1)$ & $0.2133(3)$ & $\mathrm{Zn}(1)-\mathrm{N}(3)$ & $0.2119(2)$ & $\mathrm{Zn}(1)-\mathrm{O}(1 \mathrm{~W})$ & $0.2141(2)$ \\
$\mathrm{Zn}(1)-\mathrm{N}(2)$ & $0.2164(3)$ & $\mathrm{Zn}(1)-\mathrm{N}(4)$ & $0.2179(3)$ & $\mathrm{Zn}(1)-\mathrm{O}(2 \mathrm{~W})$ & $0.2128(2)$ \\
$\mathrm{Zn}(2)-\mathrm{N}(5)$ & $0.2016(2)$ & $\mathrm{Zn}(2)-\mathrm{O}(2)$ & $0.2153(3)$ & $\mathrm{Zn}(2)-\mathrm{O}(6)$ & $0.2155(2)$ \\
$\mathrm{Zn}(2)-\mathrm{N}(6)$ & $0.2017(2)$ & $\mathrm{Zn}(2)-\mathrm{O}(4)$ & $0.2260(2)$ & $\mathrm{Zn}(2)-\mathrm{O}(7)$ & $0.2230(2)$ \\
\hline \multicolumn{1}{c}{ Angle } & $\left({ }^{\circ}\right)$ & $\mathrm{Angle}$ & $\left({ }^{\circ}\right)$ & $\mathrm{Angle}$ & $\left({ }^{\circ}\right)$ \\
\hline $\mathrm{N}(3)-\mathrm{Zn}(1)-\mathrm{O}(2 \mathrm{~W})$ & $97.13(9)$ & $\mathrm{N}(3)-\mathrm{Zn}(1)-\mathrm{N}(1)$ & $171.00(10)$ & $\mathrm{N}(1)-\mathrm{Zn}(1)-\mathrm{O}(2 \mathrm{~W})$ & $89.18(10)$ \\
$\mathrm{N}(3)-\mathrm{Zn}(1)-\mathrm{O}(1 \mathrm{~W})$ & $89.77(9)$ & $\mathrm{O}(2 \mathrm{~W})-\mathrm{Zn}(1)-\mathrm{O}(1 \mathrm{~W})$ & $86.84(9)$ & $\mathrm{N}(1)-\mathrm{Zn}(1)-\mathrm{O}(1 \mathrm{~W})$ & $97.02(10)$ \\
$\mathrm{N}(3)-\mathrm{Zn}(1)-\mathrm{N}(2)$ & $95.20(9)$ & $\mathrm{O}(2 \mathrm{~W})-\mathrm{Zn}(1)-\mathrm{N}(2)$ & $93.52(10)$ & $\mathrm{N}(1)-\mathrm{Zn}(1)-\mathrm{N}(2)$ & $77.94(10)$ \\
$\mathrm{N}(2)-\mathrm{Zn}(1)-\mathrm{O}(1 \mathrm{~W})$ & $174.93(9)$ & $\mathrm{N}(3)-\mathrm{Zn}(1)-\mathrm{N}(4)$ & $77.94(10)$ & $\mathrm{O}(2 \mathrm{~W})-\mathrm{Zn}(1)-\mathrm{N}(4)$ & $174.24(9)$ \\
$\mathrm{N}(1)-\mathrm{Zn}(1)-\mathrm{N}(4)$ & $96.06(10)$ & $\mathrm{O}(1 \mathrm{~W})-\mathrm{Zn}(1)-\mathrm{N}(4)$ & $90.15(9)$ & $\mathrm{N}(2)-\mathrm{Zn}(1)-\mathrm{N}(4)$ & $89.92(10)$ \\
$\mathrm{N}(5)-\mathrm{Zn}(2)-\mathrm{N}(6)$ & $168.56(10)$ & $\mathrm{N}(5)-\mathrm{Zn}(2)-\mathrm{O}(2)$ & $77.76(10)$ & $\mathrm{N}(6)-\mathrm{Zn}(2)-\mathrm{O}(2)$ & $112.45(10)$ \\
$\mathrm{N}(5)-\mathrm{Zn}(2)-\mathrm{O}(6)$ & $108.28(9)$ & $\mathrm{N}(6)-\mathrm{Zn}(2)-\mathrm{O}(6)$ & $77.10(9)$ & $\mathrm{O}(2)-\mathrm{Zn}(2)-\mathrm{O}(6)$ & $93.40(11)$ \\
$\mathrm{N}(5)-\mathrm{Zn}(2)-\mathrm{O}(7)$ & $99.72(9)$ & $\mathrm{O}(7)-\mathrm{Zn}(2)-\mathrm{N}(6)$ & $75.49(9)$ & $\mathrm{O}(2)-\mathrm{Zn}(2)-\mathrm{O}(7)$ & $91.74(11)$ \\
$\mathrm{O}(6)-\mathrm{Zn}(2)-\mathrm{O}(7)$ & $151.99(9)$ & $\mathrm{N}(5)-\mathrm{Zn}(2)-\mathrm{O}(4)$ & $75.08(9)$ & $\mathrm{N}(6)-\mathrm{Zn}(2)-\mathrm{O}(4)$ & $94.72(9)$ \\
$\mathrm{O}(2)-\mathrm{Zn}(2)-\mathrm{O}(4)$ & $152.81(9)$ & $\mathrm{O}(6)-\mathrm{Zn}(2)-\mathrm{O}(4)$ & $93.77(9)$ & $\mathrm{O}(7)-\mathrm{Zn}(2)-\mathrm{O}(4)$ & $94.12(9)$ \\
\hline
\end{tabular}




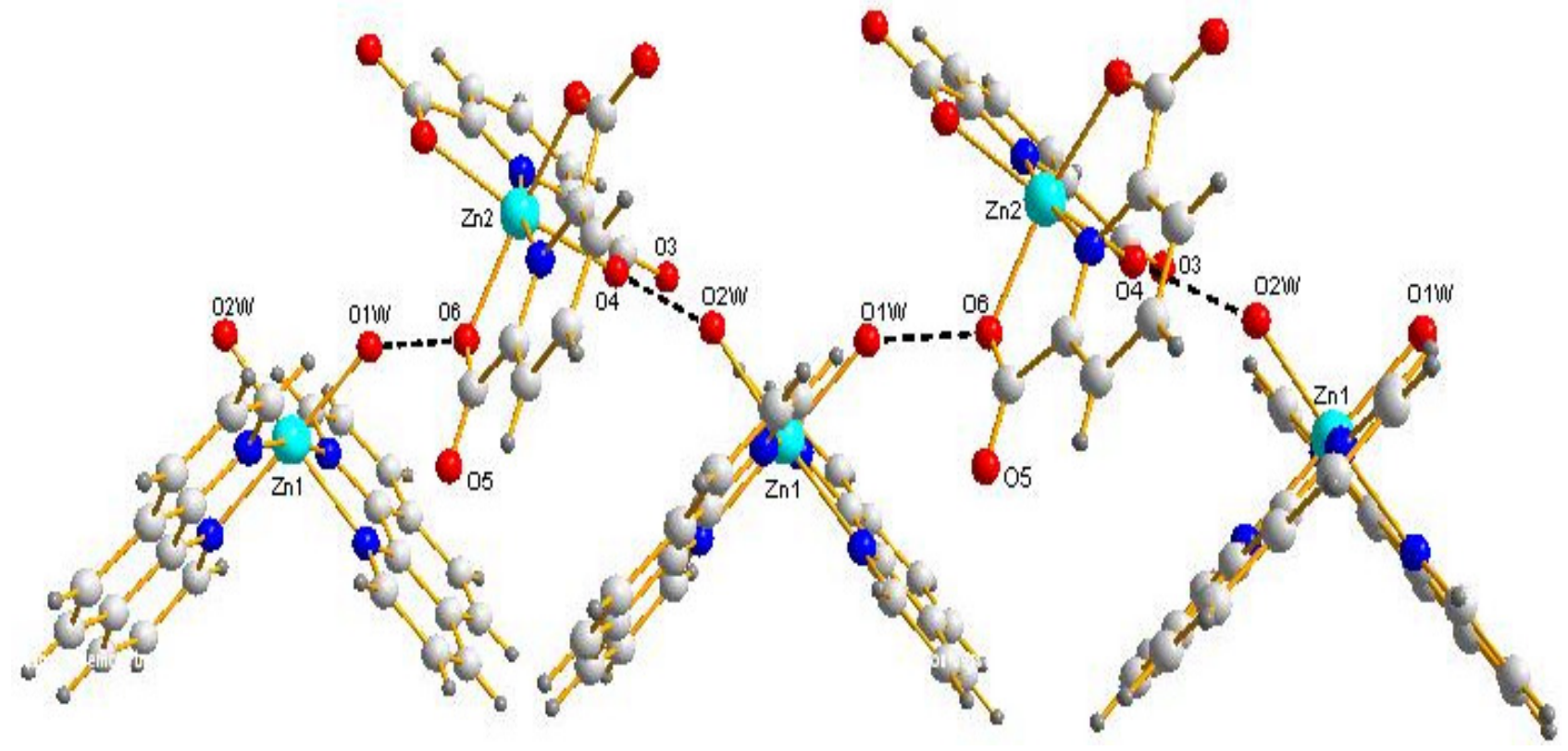

Fig. 2. Zigzag diagram of the $\mathrm{Zn}$ (II) complex; $\left(\mathrm{H}_{2} \mathrm{O}\right.$ molecules have been omitted for clarity)

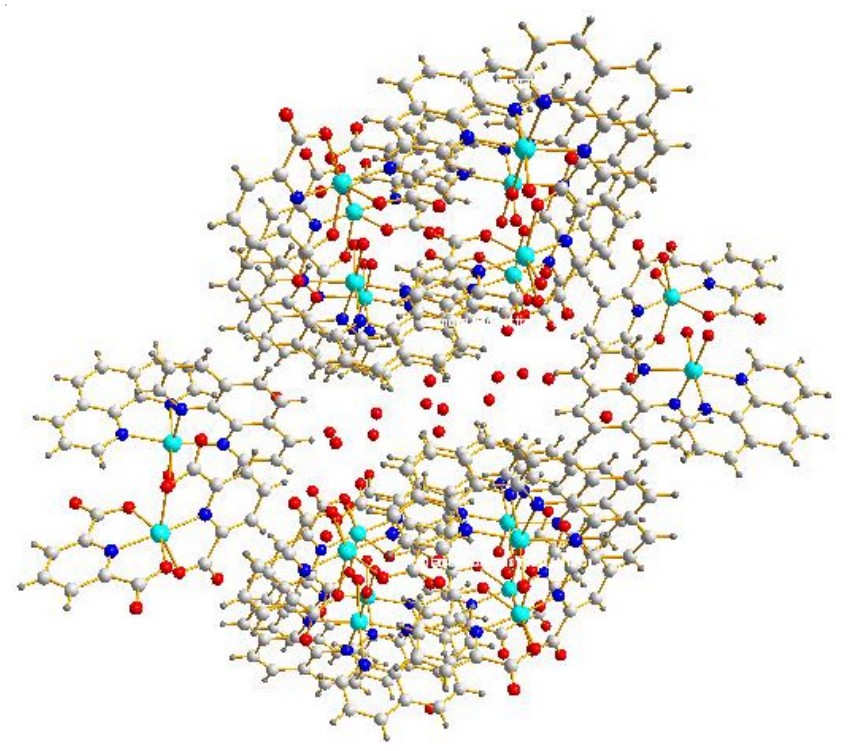

Fig. 3. Packing diagram of the $\mathrm{Zn}(\mathrm{II})$ complex

$\mathrm{cm}^{-1}$, indicating a monodentate coordination mode $\mathrm{e}^{6,12}$. Bonds at 1520 and $1430 \mathrm{~cm}^{-1}$ could be assigned to the characteristic of phen. The shift in some extent suggests that the two nitrogen atoms of phen both have participated in coordination. UVvisible absorption spectra of the title complex and the two ligands were recorded at room temperature in the wavelength range of 200-600 $\mathrm{nm}$ in ethanol solution. The absorption peaks of the complex at around 227 and $270 \mathrm{~nm}$ are assigned to the $\pi-\pi^{*}$ transition and the $n-\pi^{*}$ transition of the ligand ${ }^{5}$.

Thermogravimetric analysis: The thermal stability of the present $\mathrm{Zn}$ (II) complex was investigated under the thermogravimetric experiment. The weight loss in the range of 60-180 ${ }^{\circ} \mathrm{C}$ was $16.6 \%$, with a maximal endothermic peak appeared at $122{ }^{\circ} \mathrm{C}$, this may be attributed to the elimination of the crystal and the coordinate water molecules (Cacld. 17.2\%). Then obvious weight loss with a endothermic peak at $400{ }^{\circ} \mathrm{C}$ indicated the framework of the complex began to collapse. It didn't decompose completely at $700{ }^{\circ} \mathrm{C}$, for the mass percent of the residue $(39.8 \%)$ is geater than that of $\mathrm{ZnO}$ (Calcd. $16.4 \%)$.

Fluorescence spectra: The fluorescence of the $\mathrm{Zn}(\mathrm{II})$ complex in methanol solution was investigated at room temperature. Figs. 4 and 5 are the excitation and emission spectra, with both silts of $5 \mathrm{~nm}$, respectively.

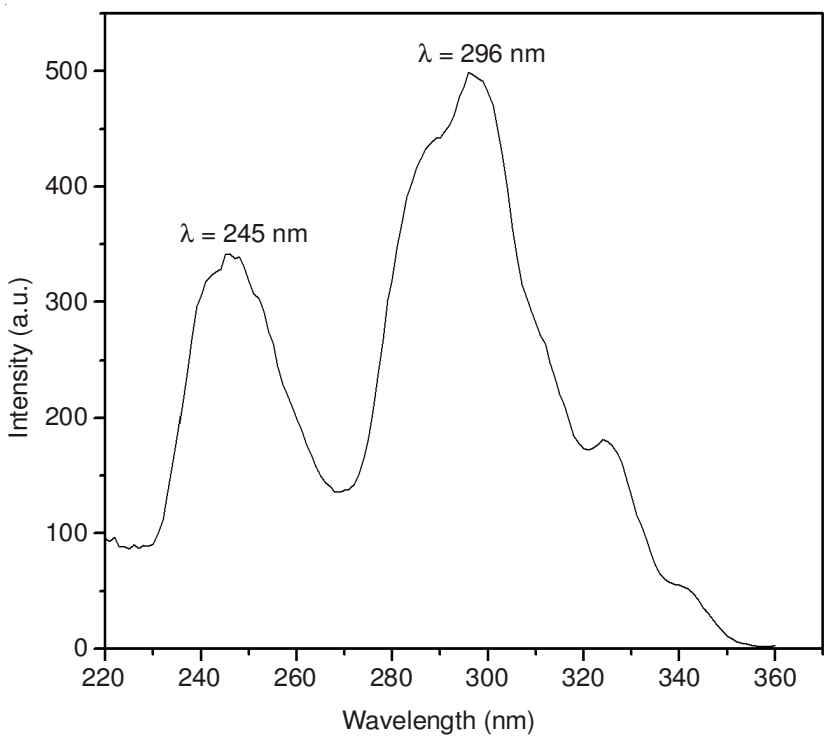

Fig. 4. Excitation spectrum of the $\mathrm{Zn}(\mathrm{II})$ complex

Present complex has strong fluorescence intensity. At the excitation wavelengths of 245 and $296 \mathrm{~nm}$, both fluorescence emission wavelengths are around $367 \mathrm{~nm}$ and the intensity of the later (a) is much stronger than that of the former (b). This intensive emission spectrum may have relationship with the rigid structure and big conjugate system of 1,10-phenanthroline. It may be caused by the $\pi \rightarrow \pi^{*}$ transition in the 1,10 phenanthroline ring ${ }^{13}$. 


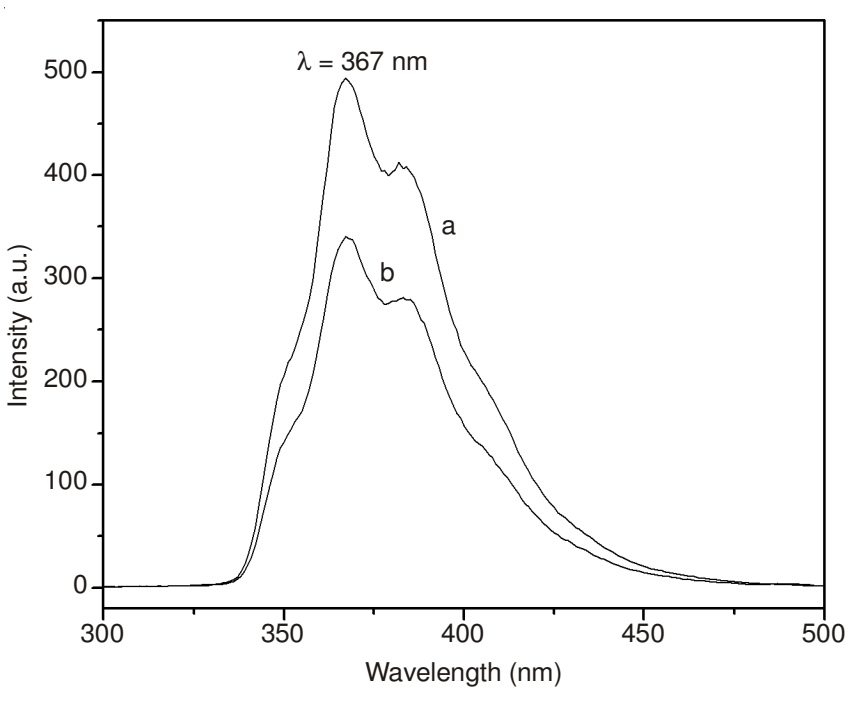

Fig. 5. Emission spectra of the $\mathrm{Zn}(\mathrm{II})$ complex

\section{Conclusion}

In summary, a new zinc(II) complex $\left[\mathrm{Zn}(\text { pydc })_{2}\right] \cdot[\mathrm{Zn}$ (phen $\left.)_{2}\left(\mathrm{H}_{2} \mathrm{O}\right)_{2}\right] \cdot 7.5 \mathrm{H}_{2} \mathrm{O}$ had been prepared and characterized. The result shows that the complex belongs to triclinic system, space group $\mathrm{P} \overline{1}$. The structure unit of this complex consists of two zinc ions with different coordination modes. Each 6coordinated geometry of the $\mathrm{Zn}$ atom is a distorted octahedral coordination geometry. The complex shows a strong fluorescence emission at around $367 \mathrm{~nm}$ in methanol solution.

\section{ACKNOWLEDGEMENTS}

The authors are grateful to the Natural Science Foundation of Henan Education Department (2011B150025) supporting this study.

\section{REFERENCES}

1. O.M. Yaghi, M. O'Keeffe, N.W. Ockwig, H.K. Chae, M. Eddaoudi and J. Kim, Nature, 423, 705 (2003).

2. R.D. Adams and F.A. Cotton, Catalysis by Di- and Polynuclear Metal Cluster Complexes, Wiley-VCH, New York (1999).

3. S. Kitagawa, R. Kitaura and S.I. Noro, Angew. Chem. Int. Ed., 43, 2334 (2004).

4. D.C. Crans, L. Yang, T. Jakusch and T. Kiss, Inorg. Chem., 39, 4409 (2000).

5. S.-Y. Chen, Y.-C. Guo, J.-W. Yan and Y.-Q. Feng, Chin. J. Struct. Chem., 30, 1064 (2011).

6. S.-Y. Chen, H.-X. Sun, Y.-C. Guo and F.-P. Cao, Asian J. Chem., 25, 3134 (2013).

7. Z.-Q. Hu, X.-Z. Ye, X.-G. Song and S.-M. Lan, Chinese J. Inorg. Chem., 27, 1557 (2011).

8. K. Hakansson, M. Lindahl, G. Svensson, J. Albertsson, J. Brunvoll, J. Spanget-Larsen, R.K. MIlanova, H. Nakata, A. Nasiri and Y. Okada, Acta Chem. Scand., 47, 449 (1993).

9. A. Moghimi, S. Sheshmani, A. Shokrollahi, M. Shamsipur, G. Kickelbick and H. Aghabozorg, Z. Anorg. Chem., 631, 160 (2005).

10. G.M. Sheldrick, SHELXS 97, Program for Crystal Structure Solution; University of Göttingen: Göttingen, Germany (1997).

11. G.M. Sheldrick, SHELXL 97, Program for Crystal Structure Refinement; University of Göttingen: Göttingen, Germany (1997).

12. C.-H. Li, W. Li, Y.-Q. Yang, C.-X. Liu and D.-P. Li, Chinese J. Inorg. Chem., 23, 1671 (2007).

13. F.-Y. Bai, X. Lü, S.-Q. Liu and X.-T. Li, Chinese J. Inorg. Chem., 27, 1261 (2011). 